\title{
Teatro para salvar el mundo
}

\author{
A theatre to save the world
}

Claire Spooner

Recebido em: 03 de fevereiro de 2021

Aceito em: 16 de março de 2021
Doctora en Filología Hispánica (Universidad de Toulouse) y en Filosofía y Letras (Universitat Autònoma de Barcelona), es profesora de lengua y literatura española en el Liceo Francés de Barcelona. En su investigación, se interesa por los puntos de encuentro entre teatro y filosofía. Es autora del prólogo de la antología Juan Mayorga. Teatro 1989-2014 y de varios ensayos sobre el dramaturgo madrileño. Contato: clairespo@yahoo.es Espanha 


\section{PALABRAS CLAVE:}

Cartografía; dramaturgia; ética; interrupción, historia.

\section{KEYWORDS:}

Cartography; dramaturgy; ethic; interruption; history.
Resumen: ¿Puede el teatro salvar el mundo? ¿Logrará abrir una grieta en el orden preestablecido? ¿Cómo dibujar la cartografía silenciosa de los vencidos de la Historia? Frente a un orden inmóvil e inamovible, frente a una cartografía trazada con mano pétrea, unívoca, la obra de Juan Mayorga se inscribe en la falla, en la variante, en el foco alejado de la elipse para proponer una cartografía de la resistencia y de la imaginación, para cuestionar aquello que a diario se impone con una única significación. Memoria, ausencia, silencio, y unas pocas palabras verdaderas son los instrumentos para construir esta cartografía de la levedad. Si la estética de Mayorga es inmediatamente ética, es porque lo que se representa es inseparable de cómo se representa. La perspectiva alterada de una tortuga, o de una niña del gueto de Varsovia solamente se puede plasmar en una estética del fragmento, la única capaz de alterar el mapa de lo visible. El teatro es esa forma de resistencia, ese templo de la intimidad de lo singular hacia lo universal, palabra y cuerpo y su temblor en el espectador, espacio de imaginación que nos recuerda que no nos hundiremos por separado. Nos salvaremos juntos.

Abstract: Can theatre save the world? Will it manage to fracture the dominant narrative and the established order? How can a silent cartography be drawn for those that were defeated and left devoid of History? The work of Juan Mayorga is permanently reframing our questions and answers, our taken-for-granted maps that have been drawn with a stern, univocal hand. In order to do so, the starting point of his work is a boundary, a geological fault, the focus that is outside the ellipse and calls for a cartography of resistance and imagination. Memory, absence, silence, and a few true words will be the tools to draw this map of lightness. If Mayorga's aesthetics is immediately ethical, it is because what is represented is blended into how it is represented. The distorted perspective of a tortoise, or of a girl from the Warsaw ghetto can only be captured in the aesthetics of the fragment, the only way to modify the visible map. Theatre is that form of resistance, that temple of intimacy. A land where the Universal Human Condition is held in a few words and bodies, an assertion of imasination revealing that we will not drown separately. We will be saved together. 
El escenario mayorguiano es un espacio en el que se da cuerpo y voz a preguntas presentadas como conflictos o dilemas. "Como los mapas, ninguna obra es neutral, está hecha a base de datos seleccionados en función de una idea y, por tanto, está constituida por preguntas morales” (Mayorga, 2011, n.p.): por esto Juan Mayorga define el teatro como un "arte político", y defiende su capacidad para examinar y cuestionar los valores que rigen el comportamiento humano, haciéndonos tomar consciencia de su complejidad. En El Cartógrafo, uno de los legados del Anciano a su nieta es que: "El mapa hace visibles unas cosas y convierte otras en invisibles" (Mayorga, 2014, 610). Asimismo, el teatro tiene la capacidad de mostrar o de encubrir aspectos de la realidad: "El teatro nació precisamente para interrogar a los dioses. Y para desenmascarar a los hombres que se disfrazan de dioses”, afirma Juan Mayorga (Mayorga, 2003, 10).

Nos proponemos en este artículo descifrar los mapas del mundo que aparecen en la dramaturgia mayorguiana, descubrir senderos que se cruzan y bifurcan, con una misma línea de fuga: la fragilidad del ser humano y la esperanza de su salvación.

1. La idea del teatro ${ }^{1}$ de Juan Mayorga

Juan Mayorga se vale de la intertextualidad para plantear cuestiones relacionadas con la escritura (teatral o no), con la interpretación, o con la puesta en escena. En Cartas de Amor a Stalin, Hamelin, Himmelweg, El Chico

1 Esta expresión está en cursivas porque alude al ensayo del filósofo español José Ortega y Gasset Idea del teatro (1958). 
de la Última Fila, El Crítico, los personajes son escritores, profesores, críticos de teatro, actores, directores de escena. A partir de situaciones concretas, Juan Mayorga plasma en el escenario reflexiones e inquietudes metateatrales e intertextuales ${ }^{2}$, dibujando los distintos mapas de su idea del teatro.

\subsection{Libros y bibliotecas en la obra de Juan Mayorga: "¿Hay algún orden?" (Mayorga, 2014: 576)}

La dramaturgia de Juan Mayorga pone de realce el poder de la literatura, a través de obras en las que los libros adquieren un gran protagonismo, y los personajes mantienen con ellos una relación vital. Por ejemplo, la pieza breve $B R G S$ escenifica una biblioteca paradigmática, en la que todas las obras están relacionadas con otras, pasadas o por venir, como los objetos de otra pieza mayorguiana mucho más reciente: La Colección. BRGS es un homenaje borgesiano a una biblioteca-palimpsesto: el propio título es un guiño al apellido de Borges, así como los nombres de los personajes.

Están en escena Jorge, quien ha leído todos los libros, menos el que Luis sostiene en sus manos, y Luis, quien se aferra a este libro único. Es una forma de escenificar la dialéctica entre lo singular y lo universal, la parte y el todo, sobre la que volveremos, pues ocupa un lugar central tanto en la estética como en la ética mayorguiana.

2 La cuestión de la puesta en escena del lenguaje en la obra de Juan Mayorga la hemos tratado ampliamente en otros artículos, como: «Entre pucheros anda Dios. Epifanías en la obra de Juan Mayorga» (en: Le créateur et sa critique. Juan Mayorga, Grimh, 2020), en «La obra de Juan Mayorga, una dramaturgia del lenguaje» (Boletín Hispánico Helvético nº19, 2012), y en nuestra tesis doctoral, citada en la bibliografía. 
En $B R G S$, el deseo de posesión y de lectura de un único libro se enfrenta a la voluntad de leer la totalidad de la biblioteca. Se escenifica entre los dos personajes un duelo verbal en torno a dos deseos contradictorios, un combate que culmina en el fracaso de la palabra: "comienzan a golpearse". Con esta acotación se termina la obra.

También El Traductor de Blumemberg dialoga con la biblioteca de babel borgesiana, puesto que el viaje en tren de los dos protagonistas gira en torno a la traducción de un libro. Un libro perdido, que se quemó durante la guerra, y parece tener una importancia crucial, tanto para su autor como para su traductor. Un libro que habla del sacrificio, que promete la salvación. Acerca de esta obra, escribe el propio Juan Mayorga: “¿es que nunca un libro os envenenó, prometiendo salvaros? ¿Algún libro os ha hecho mejores? ¿Ninguno os ha hecho peores?” (Mayorga, 2016, 315).

Sea mediante la intertextualidad (citas o alusiones a libros como en el discurso del Comandante en Himmelweg, diálogos que unen y desunen a los personajes en Animales Nocturnos, reescrituras de otras obras como Palabra de perros), o mediante su presencia directa en el escenario, la dramaturgia mayorguiana, como la casa de su infancia, está "llena de libros" (Mayorga, 2014, 767). La escritura o la lectura están estrechamente vinculadas con los deseos profundos de los personajes, hasta convertirse en el motor de su existencia (Cartas de Amor a Stalin, El Critico, BRGS, El Traductor de Blumemberg). 
Por esto también las bibliotecas ${ }^{3}$ ocupan un lugar importante en los decorados mayorguianos. En Animales Nocturnos, la Mujer Alta recibe de la siguiente manera al Hombre Bajo: "Es una casa pequeña, pero mire la biblioteca: ahí están los mejores libros del mundo" (Mayorga, 2014, 356). La clasificación de los libros de la biblioteca en función de su calidad aparece en varias obras de Mayorga, y genera debates entre los personajes.

En La biblioteca del diablo, una pieza breve de Juan Mayorga, los libros están ordenados del bien al mal: el primer libro es Job, el último, un diario, "Pesadilla" (Mayorga, 2009, 119). La idea de ordenación de la biblioteca según criterios morales se repite en La lengua en pedazos, a través de la voz del Inquisidor:

Mas cuando entro en esa ermita, no hallo el Sacramento, sino una biblioteca de muchos libros. Al tocarlos descubro que no están ordenados según el alfabeto, sino del Bien al Mal. El primero es la Biblia, el último uno de páginas negras que arde sin consumirse. A él me empujan las voces que me han guiado hasta allí, que ahora dicen como una sola: “iLee y obedece!”. "iLee y obedece!”. “iiLee y obedece!!” (Silencio.) Palabras” (Mayorga, 2014, 562).

Asimismo, en El Crítico, Scarpa (el autor) observa la biblioteca de Volodia (el crítico), y pregunta:

SCARPA: ¿Hay algún orden?

VOLODIA: Por supuesto.

SCARPA: No consigo encontrarlo.

3 La biblioteca aparece como telón de fondo en obras como: El Critico, BRGS, Himmelweg, El Chico de la Última Fila, Últimas Palabras de Copito de Nieve, Animales Nocturnos, La paz perpetua y La biblioteca del diablo. 
VOLODIA: Jerárquico. EL orden de excelencia. Si un día se desata un incendio, sé por dónde empezaré a llenar la maleta (Mayorga, 2014, 576).

La búsqueda de criterios (¿morales, éticos, filosóficos?) para ordenar las bibliotecas, se encuentra nuevamente, esta vez para justificar la disposición no de libros, sino de las piezas de una colección, en una obra mucho más reciente, inédita y terminada de escribir durante el confinamiento de 2020.

En La colección, Berna y Héctor, los coleccionistas, exponen su complejo criterio de selección de los objetos que eligen. Héctor advierte a Susana, a la que han elegido como posible heredera de su colección, de la lógica particular según la cual llegan los objetos a su casa:

Héctor- No verán carteles que orienten sus pasos, ni palabras que justifiquen las piezas. Hemos liberado a las cosas de las palabras. El título, el nombre del autor, "antiguo", "moderno", "barroco", "medieval", "renacentista", "progreso", "decadencia" ... esas palabras no valen nada ahí dentro. "No hay orden”, pensarán.

Berna- "No hay orden", pensarán. Hasta que comprendan que cada pieza está donde está para ser descubierta después de la que la precede y antes de la que la sigue. También el espacio entre ellas y sus posiciones relativas - que se hallen más o menos cerca, que una aparezca más alta o más baja, que aquella esté precisamente frente a esa otra...-, todo es resultado de una discusión que no acabará nunca.

Héctor- La colección siempre está buscando su forma (Mayorga, 2020, no prelo).

De entrada, la pareja admite que la lógica según la cual las piezas de la colección o del puzle se juntan se resiste al logos y lo pone a prueba ("Hemos liberado a las cosas de las palabras"). A pesar de este des-orden aparente, cada 
obra está íntimamente ligada con la siguiente ("La primera nos llevó a la segunda, unas nos condujeron a otras"), y forma un "todo”. Esta reflexión de Héctor parece indicar que la idea que subyace a la colección se ha ido imponiendo, ha aparecido, independientemente de la voluntad humana, hasta convertir su casa en una "casa tomada" en toda regla:

Nos hacemos la ilusión de que las elegimos y les damos un orden, pero son
las cosas las que nos escogen y se ordenan. Llegan y presentan sus exigencias,
imponen su orden, hacen visible la idea. Aquella primera obra tardamos años
en entender por qué nos había atraído. La primera nos llevó a la segunda,
unas nos condujeron a otras. Estaban por toda la casa hasta que se hizo
necesario separarlas. Les dimos la zona más silenciosa. No es una casa para
vivir (Mayorga, 2020, no prelo).

Esta colección puede ser vista como una metáfora del arte, cuya belleza representa el enigma de una presencia no funcional, inacabada por definición. La colección, que "siempre está buscando su forma", como admite Héctor, nos lleva a reflexionar sobre la elección de las palabras, esto es, sobre el lenguaje dramático, en la obra de Juan Mayorga.

Reikiavik, El Critico, Cartas de Amor a Stalin escenifican el proceso de escritura, lectura, interpretación, representación de una obra. Las tres convergen en una misma idea: un texto nunca está acabado. Una vez escrito, e incluso representado, sigue generando nuevas formas entre lectores, espectadores, actores, o escenógrafos. Afirma el dramaturgo francés Claude Régy que el espectáculo no tiene lugar en el escenario sino en la mente, en la imaginación de los espectadores o de los lectores, quienes siempre encontrarán nuevas "variantes”, nuevas posibilidades de sentido. 
La noción de "variante" es clave en la estética mayorguiana, y volveremos más adelante sobre sus raíces filosóficas. En El Crítico, Volodia pone de realce que el orden de su biblioteca es variable: "Mis dudas empiezan en el tercero. Hoy es Tres hermanas; ayer, Antígona” (Mayorga, 2014, 574). En Reikiavik, la reescritura es el tejido mismo de la obra dramática, puesto que los protagonistas imaginan e interpretan variantes en la vida y las jugadas de dos campeones de ajedrez. Asimismo, en la obra de Juan Mayorga, el "orden" de las escenas, las palabras, los sonidos y los silencios, nunca se fija, y la lógica a la que responde no es otra que la de la posibilidad de la ruptura, aquella brecha en la que aparece lo desconocido, la posibilidad del sentido.

Así, Juan Mayorga plantea la obra teatral como una "obra abierta” (Umberto Eco), como un “todo” cuyas partes se pueden desplazar o modificar, ya sean palabras en una carta, una obra, o una crítica teatral (Cartas de Amor a Stalin, El Critico), fichas en un tablero de ajedrez (siguiendo la metáfora propuesta en Reikiavik), o piezas de una colección (La Colección). En cualquier caso, se pone de manifiesto que "vacío, este lugar sería terrible”, como afirma Héctor en La Colección. Por esto, Mayorga, que creció en una casa "llena de palabras" (Mayorga, 2014, 767), puebla su escenario de palabras que se vuelven cuerpos, voces, existencias singulares y efímeras.

1.2. El teatro como arte de "hacer visible la idea". La idea en movimiento: el conflicto.

El teatro mayorguiano es un combate entre lenguajes. Entre lenguaje verbal y lenguaje visual. Entre la palabra pronunciada y otra, latente, que 
palpita en la respiración, en el hueco entre dos sonidos. Según afirma el propio dramaturgo en una entrevista:

El mundo de la filosofía y el mundo del teatro están extremadamente distanciados en la medida en que el teatro es el reino de lo concreto, de lo visible, (...), mientras que el mundo de la filosofía es el mundo de la abstracción, de las ideas, de lo intangible (Spooner, 2013, 460-461).

Aun así, "precisamente allí está el desafío, en hacer visible la idea", añade. Se trata de escenificar conflictos, ideas abstractas, a partir de situaciones concretas.

Como en Reikiavik, en El Crítico, el dramaturgo escenifica el lenguaje dramático, sus límites, sus contradicciones: el crítico y el autor no se limitan a hablar sobre la obra, sino que la representan, la vuelven concreta y visible. En Hamelin, se enuncia explícitamente el propósito de la obra: "Esto es una obra sobre el lenguaje. Sobre cómo se forma y cómo enferma el lenguaje" (Mayorga, 2014, 412). Según Anne Ubersfeld, "Le théâtre est justement l'auvre artistique qui montre le langage en situation: situation imaginaire, certes, mais visible et concrètement perceptible" (Ubersfeld, 1996, 93). Así, la crítica añade que, el teatro es un verdadero "laboratorio de observación del lenguaje". Juan Mayorga se propone desarrollar esta potencialidad, explorando el funcionamiento del lenguaje en el mundo, el "efecto de las palabras sobre la gente" (Mayorga, 2014, 223), como dice uno de los personajes de Cartas de Amor a Stalin. A la par que pone de realce el poder mágico (poder nombrador) del lenguaje, Juan Mayorga desmitifica los lenguajes del poder. 
No nos explayaremos aquí sobre el tema, ya que en otras ocasiones ${ }^{4}$ hemos reparado en la dimensión sociológica del lenguaje, y en particular en el poder simbólico de las palabras.

En Himmelweg, el Delegado de la Cruz Roja expone y comparte con nosotros su dilema: tras haber visitado el campo de Terezín, escribió un informe positivo, porque él ahí "no vio nada" fuera de lo "normal". Esta pieza cuestiona nuestra relación con lo visible, con la realidad, con aquello que, por estar bombardeados de imágenes (el lenguaje del "shock" del que habla Juan Mayorga, retomando un concepto de Walter Benjamin), ya no veremos, no queremos ver. El propio Delegado introduce la posibilidad de la duda: “¿Cree que voy a abrir esa puerta? También yo creo que voy a abrirla. Pero, ¿y si estoy equivocado, después de todo? ¿No me estaré dejando llevar por mis prejuicios? O por la arrogancia. Por la vanidad de quien cree ver más allá de lo que la vista ve. Me separo de la puerta” (Mayorga, 2014, 305).

Entre la verborrea del Comandante que quiere demostrar que es un hombre leído y se escuda en su biblioteca para justificar y construir su mascarada, y el monólogo-confesión del Delegado, que explica con sinceridad los motivos de su ceguera pasada, al espectador/lector no le queda más remedio que hacer suyos los dilemas del Delegado, preguntándose qué habría hecho él en su lugar.

Juan Mayorga escenifica el pasado desde una perspectiva actual y compleja: "Reivindico el carácter político del teatro frente a un carácter partidista que

4 "Palabra y silencio", en Diez Puertas, Emeterio (ed.), Poliedro. Acerca de Juan Mayorga, Antígona, Madrid, 2019 
no me interesa, porque creo que el partidismo tiende al maniqueísmo, a la simplificación, y nuestra misión es precisamente la de presentar lo complejo como complejo" (Vilar y Artesano, 2010, n.p.). Los conflictos entre ideas, épocas o lugares alejados, tensionan el lenguaje dramático mayorguiano y habitan tanto el escenario como la mente del espectador. La naturaleza de la imagen, como re-presentación de la ausencia es esencialmente conflicto entre presencia y ausencia, entre lo mismo y lo otro: la imagen es dialéctica. Según el filósofo contemporáneo francés Jacques Rancière, la imagen es "la présence sensible, l'esprit fait chair, l'absolument autre, qui est aussi absolument même" (Rancière, 2003, 16). Por esto, el lenguaje dramático es un conflicto que no se resuelve; apenas empieza cuando salimos del teatro.

\subsection{Idea del teatro o teatro de ideas: escenificar la tensión entre lo universal y lo singular}

Si el teatro mayorguiano es, sin lugar a dudas, teatro de texto o "teatro de ideas", hay que señalar que el dramaturgo elige poner la filosofía en boca de locutores animales (perros en Palabra de perro y en La paz perpetua, monos en Últimas palabras de Copito de Nieve, tortuga en La Tortuga de Darwin). Estos personajes plantean debates filosóficos o éticos desde una perspectiva absolutamente singular.

El perspectivismo, del que se vale Juan Mayorga para dar a ver la realidad desde múltiples puntos de vista, se inscribe en la tradición cervantina ${ }^{5}$, y en

5 Carlos Blanco Aguinaga describe de la siguiente manera los efectos del perspectivismo cervantino en "Cervantes y la picaresca": "El lector, en vez de enfrentarse a una realidad cerrada y plana que debe rechazar o aceptar, recibe [...] una realidad sobre la cual es posible meditar y hasta vacilar. 
la línea filosófica abierta por Voltaire con su Micromégas, considerada como una de las primeras obras de ciencia ficción. Este cuento filosófico narra la visita a la Tierra de un ser originario de un planeta de la estrella Sirio, Micromégas, y de un compañero de otro planeta: ambos descubren, desde una perspectiva ajena a la humana, un mundo nuevo y extraño. El asombro que experimentan da lugar a la actitud filosófica por antonomasia: la del cuestionamiento. Cipión comparte en Palabra de perros con su compañero Berganza, su asombro por descubrir que tiene el "don de la palabra": "De pronto, te encuentras a otro tan raro como tú, y tu lengua revienta de preguntas" (Mayorga, 2004, 7).

Paradójicamente, y como reconoce el propio Juan Mayorga, es en la voz de sus personajes animales donde mejor se oye su propio pensamiento: "A través del mono Copito, de la tortuga Harriet o del perro Enmanuel, me he expuesto más a mí mismo que con otros personajes" (Vilar y Artesano, 2010, n.p.).

No me hubiera consentido escribir una obra sobre, por ejemplo, un catedrático universitario que citase una y otra vez a Montaigne, a menos que hubiera intentado criticar a un pedante. Pero que el mono agonizante cite a Montaigne enriquece al personaje y, por otro lado, esas citas cobran una tensión muy especial en semejante boca. Dicho esto, creo que es importante que grandes debates filosóficos ingresen en el teatro, pero hay que conseguir que no sepulten el peso dramático de la obra. [...] Yo intento advertirme acerca de esto: que es fundamental arraigar, que el dilema filosófico, si se da, ha de depositarse sobre sangre y sobre carne (Ibidem).

[...] Toda la verdad absoluta, todo el desengaño con que pretende aleccionar Berganza, no pasa de ser un punto de vista en el gran coloquio del mundo. Como ya decía Américo Castro hace muchos años: "no espejo plano, sino prisma" (Aguinaga, 1957, 331). 
En Últimas palabras de Copito de Nieve y en La paz perpetua, Mayorga dialoga explícitamente con los escritos de Montaigne y de Kant (los textos y los conceptos se citan, se comentan), desde una situación singular que sitúa de entrada de juego el debate filosófico en la ironía, invitándonos a tomar distancia, a cuestionar, dudar, y asombrarnos siempre. El planteamiento de cuestiones universales desde perspectivas "alteradas" resulta pues, ser una elección tanto estética como ética.

Asimismo, en La Colección, Berna y Héctor hacen hincapié en lo singular de cada una de las piezas de su colección, aun formando parte de un "todo". Cada objeto se relaciona de manera singular con el conjunto al que pertenecía antes, para formar uno nuevo:

Hay cosas que, fuera de aquí, serían basura, otras cuyo único valor es aquello de que fueron arrancadas y otras que pertenecieron a reyes. Algunas fueron hechas por artistas. Hay obras que rescatamos de las manos de los restauradores - ninguna está restaurada. Hay obras dañadas. Hay obras que concentran el espíritu de su época y obras hechas contra su época. Hay obras duplicadas y hay plagios. Hay imágenes que contienen la entera escala de la experiencia humana e imágenes inhumanas.

Berna- Hay piezas enormes que en la colección parecen pequeñas y lo contrario. Hay piezas minúsculas y otras que no se abarcan con la mirada (Mayorga, 2020, no prelo).

La esencia de esta extraña colección nos permite aproximarnos a la (est) ética que sostiene el tejido dramatúrgico de Juan Mayorga. En su colección, "hay piezas minúsculas y otras que no se abarcan con la mirada", dice Berna. Se puede leer entre líneas la metafísica de la mónada de Leibniz, a partir de la que Walter Benjamin introduce el concepto de la "imagen dialéctica”, 
definida de la siguiente manera en la tesis doctoral de Juan Mayorga: "La idea es mónada - lo que, brevemente, quiere decir: cada idea contiene la imagen del mundo" (Mayorga, 2003, 43).

Por una parte, los elementos de la colección plasman la idea filosófica de la mónada de Leibniz, y por otra, remiten a una cuestión de estética, recordando que la obra de arte (singular) se concibe como un modo de expresión del todo. Según analiza el propio dramaturgo: "Schlegel - anota Benjamin - ve en el arte la posibilidad de expresar la suprema universalidad como individualidad; esa posibilidad se basa en que "toda poesía, toda obra debe significar el todo" (Mayorga, 2003, 105).

Asimismo, la dramaturgia de Juan Mayorga parece ser un modo de expresión de "la solución monadológica", en la que "lo concreto no es suprimido por mor de lo general, sino que coincide con lo absoluto, se constituye en lugar de la verdad. "La verdad es concreta", leerá Benjamin junto al escritorio de Brecht" (Mayorga, 2003, 43). Se trata de "volver visible" la idea: las situaciones o relaciones entre personajes contienen la imagen del mundo entero.

Por otra parte, Walter Benjamin relaciona la dialéctica entre lo singular y lo universal con la estética de la ruina barroca. En la ruina (a la que Héctor alude en su descripción de la colección: "hay piezas cuyo único valor es aquello de lo que fueron arrancadas"), en el fragmento, se percibe la totalidad: "Lo que ahí yace reducido a escombros, el fragmento altamente significante, el mero trozo, es la materia más noble de la creación barroca” (Benjamin, 2006, 397). Desde la ruina se ve el edificio entero, lo que fue y lo que puede llegar a ser. 
De nuevo, la filosofía y la estética están íntimamente ligadas en la idea del teatro de Juan Mayorga. La estética del fragmento, o de la ruina, se junta con un propósito ético fundamental en el "teatro histórico” de Juan Mayorga: el de visibilizar la historia de los olvidados, aquella que no ha sido escrita.

\section{ESTÉTICA DE LA INTERRUPCIÓN Y BÚSQUEDA DE LA VERDAD}

\subsection{Estética de la variante}

En La Colección, el dramaturgo plantea la existencia de un conjunto heterogéneo de objetos no funcionales que cobran sentido el uno en relación con el otro, con el que estuvo a su lado y con el que vendrá. La colección es una idea, variable y movediza, que todavía no encontró su forma, afirman Héctor y Berna. Asimismo, la disposición de las escenas en las piezas de Juan Mayorga, su cartografía particular, está también pensada desde la idea de la variante, como lo muestra muy bien Reikiavik.

En esta obra, Bailén y Waterloo escenifican la búsqueda de nuevas "variantes" en la partida y en las vidas de Fischer y Spassky, los protagonistas del gran campeonato mundial de ajedrez, en 1972. La situación singular de la partida del americano Fischer contra el ruso Spassky contiene y refleja un tablero mucho más universal, el del mundo escindido en dos durante la Guerra Fría.

La "variante", las combinaciones posibles escenificadas en Reikiavik, nos recuerdan que el lenguaje dramático de Juan Mayorga bebe del lenguaje matemático y que, para el dramaturgo, la escritura es reescritura. La (re) escritura a partir de variantes crea un tejido de repeticiones y diferencias. El 
filósofo francés Jacques Derrida entiende la repetición de lo mismo no como suma o síntesis, sino como diferencia, alteración característica del regreso a lo mismo: "Le retour au même ne s'altère - mais il le fait absolument-que de revenir au même. La pure répétition, ne changeât-elle ni une chose ni un signe, porte puissance illimitée de perversion et de subversión" (Derrida, 1967, 431).

Así, la posibilidad de la diferencia se encuentra en aquellos personajes mayorguianos que escriben y reescriben (Bulgákov en Cartas de amor a Stalin, el alumno prodigio en El chico de la última fila, el Delegado en Himmelweg), pero también, en el posible desfase entre las acciones enunciadas en el texto y las que se ven en el escenario. En Hamelin, el Acotador sugiere que la escritura textual y la escénica sean diferentes, e incluso, contradictorias:

Ni interpretación ni puesta en escena tienen por qué ser redundantes con lo que el Acotador dice, sino que podría ocurrir lo contrario, que estuviesen en tensión. Es decir, si el Acotador dice "Están tomando un café", pues probablemente lo más interesante es que hagan cualquier otro tipo de cosa, o sea que hagan incluso cosas que estén en tensión con eso, visualmente (Spooner, 2013, 483).

La diferencia se entiende como la posibilidad de otra cosa, de otro sentido, que mantiene al receptor (espectador, lector) en estado de alerta.

Himmelweg, por ejemplo, es una obra cuyo tejido dramatúrgico se compone de repeticiones y variaciones: los ensayos de los "actores" judíos (antes de la visita del Delegado de la Cruz Roja) y la narración de la "representación" (cuando ya ha tenido lugar) desde voces distintas (monólogo del Comandante, monólogo del Delegado). En esta obra, la 
repetición representa la sumisión a través de la mecanización de los gestos de los judíos, que tienen que reproducir un papel que se les ha asignado. Pero lo más interesante es que la repetición conlleva la posibilidad de la alteración del gesto automatizado. En el desfase entre la palabra y el gesto aparece la posibilidad de la rebelión, y asoma la verdad del personaje.

La subversión es variación silenciosa de la repetición. Juan Mayorga destaca en una entrevista el valor del silencio en Himmelweg, en la medida en que no pretende dar voz a las víctimas sino "amplificar el silencio, hacer que resuene (su) silencio":

Entonces en este sentido, el silencio en Himmelweg, ese silencio que yo creo que hay que hacer que suene, ha de sonar por ejemplo también en las escenas de humo donde están ahí los judíos haciendo las escenas y nos damos cuenta de que se salen del guion, o no saben actuar. Entonces en ese silencio, paradójicamente, estaría la verdad de ellos. Si por ejemplo entre los niños de la plaza, de pronto hay uno que hace algo, otra cosa que lo que dice, ahí está la verdad de este personaje, quienes son realmente (Spooner, 2013, 470).

El horror de los campos de concentración aparece precisamente ahí, cuando se introduce una variación en las repeticiones automatizadas o en el guion, cuando el gesto no se corresponde con la palabra. En esta brecha singular surge la verdad de los judíos, aquello que las palabras no pueden abarcar.

\subsection{Interrupciones en Himmelweg}

Si bien Himmelweg se compone de cinco actos, está lejos de seguir una cronología lineal: estos actos son cinco interrupciones, cinco variantes. Desde 
distintas voces narrativas, con distintos cuerpos, se escenifica el antes y el después de la mascarada fallida del Comandante frente al Delegado de la Cruz Roja. Así, se representa el pasado no tanto desde el discurso sino desde el vacío o el silencio, como ocurre también en El Cartógrafo, obra sobre la que nos detendremos más adelante, y en El Jardín quemado. Esta última transcurre en un hospital psiquiátrico, cuyo jardín - un jardín de cenizas -, oculta a la par que las revela, por intermitencias, las derrotas y locuras de la guerra civil espańola. Despertando preguntas, agitando consciencias, sin dar respuestas. Las obras de Juan Mayorga que presentan como telón de fondo la guerra civil espańola (El Jardín quemado) o la Segunda Guerra mundial (El Cartógrafo y Himmelweg) plantean la pregunta de Theodor Adorno: buscan la manera de "escribir después de Auschwitz". Y todas ellas, coinciden en un mismo punto: evidenciar el fracaso de la comunicación, del "logos", de la experiencia comunicable, desde la Primera Guerra Mundial hasta hoy en día. En esta imposibilidad de decir o de mostrar, reside sin embargo la posibilidad de dar a oír, de interrumpir el discurso para, en el silencio, soñar otro mundo. Por esto en Himmelweg, tanto el lenguaje como la estructura giran en torno a la falla y a la interrupción, en las que puede surgir lo fallido de la Historia.

El Comandante del campo, dramaturgo y director de escena, decide representar una mascarada. Sin embargo, parece "amable y culto", diserta acerca de literatura y composición de obras, basándose en los escritos de Aristóteles, citando a varios autores europeos, haciéndonos soñar con un mundo en el que reine la paz. En algún momento, ciertamente, nos dejaremos 
llevar su discurso: de entrada, Juan Mayorga sitúa a sus lectores/espectadores en una postura incómoda.

Tendremos varios guías a lo largo de las visitas del campo: el Comandante, cuya finalidad es enmascarar el horror, el Delegado, testigo directo de la Historia, que comparte su experiencia y nos quiere convencer de que, en su lugar, habríamos visto y escrito lo mismo que él, y Gottfried, uno de los "actores judíos", el que encarna al "alcalde" de la "ciudad". Su discurso, impostado, y su "extrańa" actitud, nos hacen dudar a cada instante de lo que vemos, de lo que oímos. Así, sin la menor intención de enseñarnos el camino a seguir, estos guías nos llevan de la mano hasta la más grande de las encrucijadas, y, una vez ahí, Juan Mayorga nos pide que participemos activamente en la búsqueda incesante de la verdad.

Durante su monólogo, el Comandante cita el capítulo VII de la Poética de Aristóteles, acerca de la composición de la obra: "Lo que Aristóteles viene a decir es que una obra de arte es tanto más bella cuanto más compleja, siempre y cuando esa complejidad esté bajo control” (Mayorga, 2014, 319). Esta complejidad es también la que busca Mayorga en su obra, pidiéndole al lector que participe en la construcción colectiva del sentido. El dramaturgo ha hecho hincapié en varias ocasiones sobre la necesidad de recuperar el ágora, la asamblea.

En "Huellas de la Poética de Aristóteles", Germán Brignone relaciona Himmelweg con la estructura de la tragedia griega. En particular, resalta la figura de Gottfried: el maestro del coro. Por otro, la del Comandante: el corego "encargado de cuidar los detalles de la producción de la representación 
y de pagarle al maestro de coro y a los actores, en ese caso, con la promesa de conservar su vida" (Brignone, 2011, 73). Finalmente, el arconte encarnaría el Berlín "ausente" de la extraescena, esta ciudad personificada que representa el poder del gobierno alemán, de Hitler: "Berlín nos ha elegido" (Mayorga, 2014, 317).

Además, como en las tragedias griegas, en Himmelweg escenifica un dilema ético: el del Delegado de la Cruz Roja, quien escribió un informe positivo sobre el campo. También experimenta este dilema el espectador, quien se deja embaucar por las palabras del Comandante, por las del Delegado, pero experimenta la duda en cada interrupción del discurso.

ELLA- ¿Tú no los oyes? Los trenes.

ÉL- Mucha gente está esperando que cometa un fallo para ocupar mi sitio. Si el jefe me ha puesto al cuidado de la balanza...

ELLA- ¿Qué haces para no oírlos?

ÉL- $\quad$ Si el jefe me ha puesto al cuidado de la balanza, es porque confía en mí. Todo lo que entra y sale en el almacén...

ELLA- Mira ahí. El humo. ¿No lo ves? ¿Qué haces para no verlo? (Mayorga, 2014, 310).

En Himmelweg, la verdad aparece en la brecha entre el texto y lo visible, y somos nosotros, los espectadores, quienes podemos decidir oír o ver más allá de lo visible, de lo decible. Las preguntas de la chica del banco ("Ella"), a propósito del ruido de los trenes, del humo, se enfrentan al obstinado silencio del chico ("Él"). Éste niega las interrupciones del discurso planeado, y opta por continuar con su guion. Aquí, el desfase entre los interlocutores 
en el diálogo es lo que vuelve visible más allá (o más adentro) del lenguaje: lo reprimido o escondido, aquello que no se puede decir.

Pero no solo se trata de interrupciones del discurso, sino también de los gestos. El Delegado observa en la actitud de los actores judíos cierta extrańeza:

\begin{abstract}
Se mueven con torpeza, con inseguridad. (...) Todos me dirigen una extrańa mirada. También los niños que juegan a la peonza, (...) Su peonza rueda hasta caer junto a las botas del comandante, Los niños se miran sin saber qué hacer, como si ese momento no estuviese previsto. Gottfried deja de hablar, como si tampoco él supiese qué hacer. El comandante se agacha a coger la peonza. Me pregunto si no será también él, el comandante, una pieza del mecano. Demasiado amable, demasiado culto (Mayorga, 2014, 303).
\end{abstract}

Un gesto imprevisto, que no forma parte de la "obra" escrita por el Comandante, es una interrupción que hace peligrar su proyecto de enmascarar la realidad. El fallo se convierte en falla, y en ella acecha la verdad de los judíos.

El equilibrio entre lo sencillo y lo complejo recomendado por Aristóteles, es también aquel punto de encuentro entre lo singular y lo universal que sostiene y tensiona la escritura dramatúrgica mayorguiana, y que bebe de la filosofía de Walter Benjamin: "Los flecos son importantes. En los flecos se conoce el tejido" (Mayorga, 2003: 42). O, como le dice el Anciano a su nieta en El Cartógrafo: "Las cosas importantes solo se ven a pequeńa escala" (Mayorga, 2014, 615).

Brignone relaciona Himmelweg con otro concepto benjaminiano, el de la imagen dialéctica, que junta focos o interrupciones, flecos o fallas, para crear una constelación que reúne opuestos: 
Entendemos que, en Himmelweg, Juan Mayorga desarrolla tal peripecia cuestionándose -y cuestionándonos- acerca de la singularidad y la universalidad mediante la complicidad de lo simple; el nudo y la madeja; la experiencia individual y la colectiva. La diferencia entre el baile de la peonza y un trozo de madera. Esto es, preguntarse cómo la imagen dialéctica anuda dos tiempos. Dos interrupciones (Brignone, 2011, 102).

La imagen dialéctica rompe con la temporalidad lineal y confía en la interrupción, la variante o la diferencia, para que asome la verdad. ¿Cómo representar la verdad sin fijarla? ¿Cómo mantener la tensión entre lo universal y lo singular?

Si bien en Himmelweg el Comandante insiste en que el Delegado puede sacar todas las fotos que quiera para dar a ver al mundo la "realidad" de lo que ocurre en esta "ciudad autogestionada", en La Colección, Héctor y Berna advierten a su visitante: "Antes de entrar, permítannos hacerles algunas advertencias. No pueden hacer fotos, pero sí dibujos o mapas" (Mayorga, 2020, n.p.). Así, a partir de distintos soportes, fotografías (La mala imagen, Himmelweg), mapas o dibujos (El cartógrafo, Los yugoslavos), la realidad (pasada, presente o futura) se dibuja, se borra, se reescribe, y, sobre todo, se cuestiona: "En una foto siempre hay respuestas a preguntas que nadie se ha hecho. En el mapa solo hay respuestas a las preguntas del cartógrafo. ¿Cuáles son tus preguntas?” (Mayorga, 2014, 617).

Del mismo modo, los mapas que surgen en la mente del espectador/ lector son el resultado de sus preguntas y de su interacción constante con la realidad observada (tanto la del escenario como la que se sugiere fuera del escenario). Philippe Ortel define el mapa como una "matrice d'interactions 
potentielles" (Ortel, 2008, 6). La interrupción y la variabilidad, que fomentan esta interacción y dibujan distintos focos, lugares o posibilidades en la representación de la realidad, son elementos clave en la estética mayorguiana y herederos de la filosofía de Benjamin. En los silencios de la cartografía mayorguiana acecha la esperanza, dentro de la desesperanza.

\section{UnA CARTOGRAFíA DE LA AUSENCIA}

\subsection{El Cartógrafo: un relato topológico}

Hemos visto que Juan Mayorga rompe con el tiempo lineal, introduciendo la interrupción y la fragmentación del discurso como recursos creadores de sentido. Esta ruptura, heredera de la filosofía benjaminiana, también se percibe cuando analizamos el tipo de relato escenificado en algunas de sus obras. Como los mapas, en lugar de narrar una sucesión de acontecimientos que avanzan hacia una finalidad, la obra de Juan Mayorga muestra posturas en el tiempo y en el espacio.

El cartógrafo sería un claro ejemplo de relato topológico. En esta obra, le corresponde al lector/espectador desarrollar la intriga y construir el sentido, relacionando fragmentos, tejiendo puentes entre las 32 secuencias de la obra, que llevan al escenario personajes que recuerdan, que (se) buscan, que se cruzan.

La acción tiene lugar en Varsovia. Las secuencias en presente escenifican una pareja. Raúl trabaja en la embajada de España en Varsovia, Blanca es una mujer sensible con tendencias depresivas. Durante un paseo solitario por la ciudad, ella visita una exposición sobre el gueto de Varsovia durante 
la ocupación alemana. Ahí descubre la historia de un cartógrafo judío que tuvo que esconderse en su casa, y que sobrevivió gracias a los cuidados de su nieta. La leyenda cuenta que la niña, además de llevarle comida a su abuelo a escondidas, se convierte en su cómplice y comparten el proyecto de dibujar un último mapa, el del guetto, para dejar testimonio de una realidad bárbara. Como Don Quijote, según quien "medimos toda la tierra con nuestros mismos pies", la niña mide el guetto con sus pies para darle a su abuelo la información necesaria para el trazado del mapa. Atrapada por esta historia, Blanca se lanza en la búsqueda del mapa perdido. Las demás secuencias de El Cartógrafo, que se van yuxtaponiendo con las que representan la actualidad (el presente de Blanca), tienen lugar en los años 1940-43: cuentan la historia de un Anciano cartógrafo y de su nieta que viven en un gueto, el gueto de Varsovia.

A medida que transcurre la obra, entendemos que estas escenas nos podrían dar la clave del misterio de la leyenda que obsesiona a Blanca. Aun así, hasta el final de la obra, permanece la duda: no sabemos si estos dos personajes del pasado y su mapa existieron realmente o no. Aunque Blanca se encuentra finalmente con una cartógrafa judía, Deborah, que sobrevivió a la destrucción del guetto, ésta afirma: "siento decepcionarla, no me hubiera importado serlo, pero no soy aquella niña", e insiste: "No soy aquella niña" (Mayorga, 2014, 646). Pero tras esta negación obstinada, Deborah se deja llevar por los recuerdos, y evoca en su monólogo final imágenes que hacen de nuevo posible la duda: 
Desde aquí había mil doscientos pasos hasta la escuela, ahí formábamos la cola de la sopa. Aquí estaba mi casa, orientada hacia el sur, en invierno teníamos luz hasta las tres. Ahí estaba el cuarto de mi padre, ahí mi cuarto, en el desván teníamos la mesa de los mapas. El muro pasaba por aquí. Unos centímetros, eso era todo. Aquí está, Umschlagplatz, de aquí salían los trenes. Aquí vi a mi abuelo por última vez (Mayorga, 2014, 649).

La repetición de los deícticos ("aquî", "ahî”, “aquí está”) evoca, sin llegar a dibujarlo, el recuerdo del mapa que Deborah lleva consigo desde hace años. La palabra hace existir el mapa del gueto, sin volverlo nunca visible sobre el escenario. Como afirma la cartógrafa, si se hiciese una película o una obra de teatro sobre la "leyenda" de la niña del gueto, "el mapa no debería aparecer, siempre resultaría decepcionante" (Mayorga, 2014, 648).

Sin duda Juan Mayorga coincide con la opinión de la cartógrafa: recordemos que en Himmelweg tampoco aparece la realidad de los campos, sino que se representa una mascarada creada por el Comandante de un campo de concentración, una "obra de teatro" para un solo espectador: el Delegado de la Cruz Roja. Por esto podemos decir que los mapas que prevalecen en la obra de Juan Mayorga son los de las ausencias. No son mapas visibles, sino que se dibujan entre las palabras, se perciben a través de imágenes efímeras (creadas por las palabras). Estos mapas son como elipses cuyos focos, distantes y dispares, siempre incluyen un no lugar, un espacio olvidado, un espacio que no se representa en el escenario (fuera de campo), pero para el que se desarrolla toda la acción. El mapa que Blanca busca, el que Deborah recuerda, nunca aparecen sobre el escenario, pero son el motivo por el cual estas dos mujeres luchan o han luchado. 
El último mapa, como la última palabra, es siempre del espectador, quien es testigo del diálogo entre dos historias, la de la nińa encargada de elaborar "el mapa de un mundo en peligro" (Mayorga, 2014, 362), y la de Blanca, que dibuja otro mapa: el de la memoria silenciada del gueto, el de "Hurbineka" (Mayorga, 2014, 621). En esta búsqueda por visibilizar lugares y personas olvidadas, se dan a oír los silencios de la Historia.

\subsection{Mapas, miradas elípticas que ensanchan el campo de los posibles}

En el gesto de tres mujeres (Blanca, Deborah, y la niña del guetto), anida la posibilidad de "despertar a los muertos" según una expresión de Walter Benjamin (Benjamin, 2000, 344). Por esto el "teatro de la memoria" de Juan Mayorga se desmarca del "teatro histórico", asociado a la historiografía tradicional que escenifica una "Historia museo": en el escenario mayorguiano aparece una "memoria viva" (Eduardo Galeano).

Todos los personajes de la obra son o se vuelven cartógrafos: de la ciudad, actual o pasada, de su propio cuerpo, de cuerpos ajenos. El Cartógrafo es una puesta en abismo de la escritura como cartografía: el dramaturgo se convierte en un cartógrafo que dibuja su propio mapa del mundo, plasmándolo en escenas, en imágenes que irrumpen en el escenario y se quedan suspendidas, fuera del tiempo y del espacio. En esta obra hay escenas, imágenes en suspensión, que rompen con la temporalidad lineal, y dibujan los contornos de la imagen dialéctica de Walter Benjamin, en la que pasado y presente se reúnen en una misma constelación. El dramaturgo escribe en su tesis doctoral: 
"La imagen dialéctica es un no lugar. Como el desierto por el que el pueblo camina con una única certeza: Dios no está aquí” (Mayorga, 2003, 238).

La "cartografía de la ausencia" (Mayorga, 2014, 644) que dibuja Juan Mayorga en El Cartógrafo se va modificando y tensando en función de los lugares o focos que los personajes deciden visibilizar, y plasma lo que Juan Mayorga llama una "mirada filosófica": "Una mirada que, al entrar en un lugar, vea elipses - una mirada que vincule puntos distantes; que incluso vincule un punto interior, a la vista, con otro exterior (invisible) al lugar, rompiendo los límites de éste" (Mayorga, 2010, 372). La cartografía de Juan Mayorga es capaz de abarcar temporalidades actuales y pasadas, porque busca entre las voces del presente las que fueron enterradas. El Anciano le revela a su nieta que "lo más importante del espacio es el tiempo" (Mayorga, 2014, 611), y más adelante toma el relevo Deborah, cuando afirma que "lo más difícil de ver es el tiempo" (Mayorga, 2014, 649). Esta sinestesia entre tiempo y espacio está presente en una mirada elíptica que bebe de la filosofía de la Historia de Walter Benjamin.

$\mathrm{Al}$ reunir en una misma figura focos distantes (presentes o pasados, visibles o invisibles), Juan Mayorga dibuja un tiempo heterogéneo, que produce mapas actuales del mundo. Walter Benjamin define el tiempo como JetztZeit ${ }^{6}$ : "Al instante vacío y cuantificado, (Benjamin) opone un "tiempo-ahora" (...) que resume (...) la historia de toda la humanidad" (Benjamin, 2000,

6 En Infancia e historia, Giorgio Agamben traduce esta noción como "tiempo-ahora" (2002, 182), Daniel Bensaïd en Walter Benjamin Sentinelle Messianique (2010, 12), lo traduce como "tiempo actual". 
442). Este tiempo, reversible y heterogéneo, junta dos instantes opuestos, el origen y el final, en una misma constelación o imagen dialéctica.

Juan Mayorga propone en su teatro de la memoria (pensamos en obras como El Cartógrafo, Himmelweg, El Jardín quemado, o La Tortuga de Darwin) una topología de la historia que vincula presente, pasado y futuro en un mismo mapa, convirtiéndolo en una elipse o en una imagen dialéctica. "Los mapas cubren y descubren, dan forma y deforman" (Mayorga, 2014, 610). De ahí también la variabilidad de los soportes de los mapas: en $E l$ Cartógrafo, se dibujan en un papel, se esculpen en paredes o en el envés de baldosas, en la tierra, o en el mismo cuerpo de los personajes.

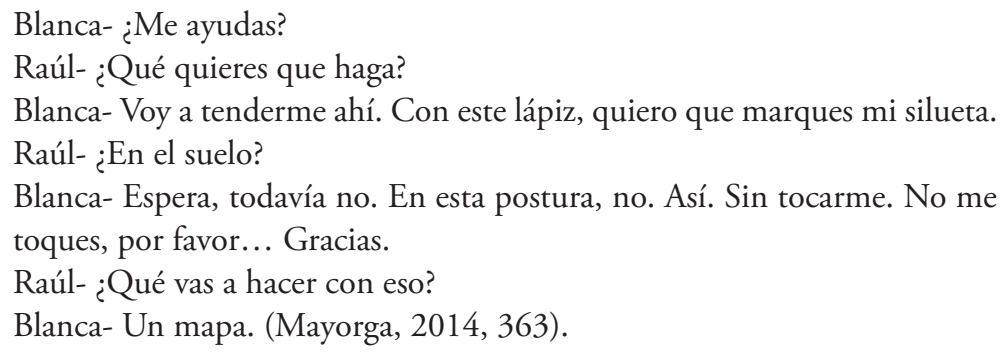

Una vez dibujados los contornos de su silueta, Blanca podrá observar en su interior aquellos lugares e instantes que atravesaron y marcaron su existencia. Aparece nuevamente la relación entre la memoria y la vida, entre lo universal y lo singular.

Blanca - Miras tu cuerpo y aparecen cosas. Personas, animales, palabras. Colores, fechas. Sonidos. Lugares. Madrid. Varsovia. Londres. Cosas que estaban separadas, aparecen juntas. Cosas olvidadas vuelven. Tú cuando te conocí. Alba el día que nació. Alba el primer día de colegio (Mayorga, 2014, 385). 
El cuerpo es el lugar de la memoria, en el que surgen los acontecimientos traumáticos de la vida de Blanca. Entre ellos, la pérdida de su hija, que, si bien se menciona una única vez en la obra, ocupa un lugar fundamental, pues sin duda tiene que ver con el motor de la búsqueda iniciática de la niña del gueto. Blanca se vuelca en la historia de una niña sin madre, y en su indagación está el silencio de la pérdida de su propia hija. Las dos niñas ausentes son los puntos que tensionan y justifican el conjunto de la obra.

La cartografía de la ausencia otorga un lugar importante al silencio. En nueve secuencias de la obra, Juan Mayorga apuesta por escenas mudas, en las que una breve acotación llena toda la escena: "La Niña mide distancias con sus pasos. Blanca dibuja en la tierra un mapa. Deborah camina sin rumbo" (Mayorga, 2014: 368). La niña del gueto mide el mundo con sus pies, con la esperanza de salvarlo, Blanca dibuja las huellas del mapa perdido en la tierra, mientras que Deborah, la anciana que fue cartógrafa, ha dejado de fijar sus pasos en mapas, y camina ahora "sin rumbo". Esta secuencia junta en un ritmo ternario a tres generaciones de mujeres en un mismo espacio y temporalidades distintas, dibujando imágenes poéticas que "fixent le passé comme matériau du possible" (Bensaïd, 2010, 126).

\section{3. "Hay mapas que salvan"}

El Anciano y Marek explican en El Cartógrafo que los mapas pueden servir propósitos muy diversos, e incluso contradictorios entre sí. Marek comenta las fotografías de la exposición de la sinagoga, recordando que los 
mapas son un dispositivo que permite el control de la sociedad: "El mapa más exacto siempre lo hace el enemigo. No conozco otro mapa del gueto, ni creo que haya otro que este: el gueto desde el punto de vista de los asesinos" (Mayorga, 2014, 360).

Pero la obra evidencia que los mapas también pueden ser un gesto de huida o de resistencia: todo dispositivo de control comprende sus propias "fallas". Por ejemplo, los mapas que Deborah dibuja desde que está jubilada son "mapas útiles", están destinados a ayudar a los republicanos a dejar España, a permitir a los habitantes de Trebezín y de Saravejo a huir de su ciudad, a indicar el camino a seguir para los inmigrantes de África del norte que viajaban clandestinamente por Europa: "Esto es el campo de Treblinka, escala uno a mil. Ruta Fietkau: con este plano en la mano, algunos consiguieron cruzar a tiempo los Pirineos. Hay mapas que matan y mapas que salvan" (Mayorga, 2014, 648). O, más adelante: "Mapa de Europa para africanos. Desde que me jubilé, solo hago mapas útiles. Cómo entrar, dónde obtener ayuda... Mapas para gente que huye. Yo veo el mundo desde el gueto" (Ibidem).

También el mapa de la niña del guetto le podría permitir salir de ahí, y salvar también a otras personas, como le dice su abuelo: "Sabes cómo salir. Puedes sacar gente. Utiliza lo que sabes para salvar tu vida y la de alguien más, el que tú quieras. Una vida es más importante que todos los mapas del mundo (Mayorga, 2014, 628). ¿Salvarse, o quedarse dentro, para seguir construyendo la memoria? En realidad, no se trata de una disyuntiva, pues los mapas son el dibujo inacabado de una "memoria viva”: "Si todavía hay 
un modo de escapar, tú lo encontrarás. Es necesario que te salves. No por ti. Por cada uno de ellos. Nadie sabe lo que ha pasado aquí como lo sabes tú. Si tú puedes escapar, tu deber es contar al mundo lo que has visto" (Mayorga, 2014, 645).

Como Deborah, Juan Mayorga dibuja "cartografía(s) de la ausencia" (Mayorga, 2014: 646), mapas del mundo que buscan la manera de "encontrar una salida" (Deleuze et Guattari, 1989, 15). En Palabra de perro, Cipión y Berganza, los protagonistas de la novela ejemplar cervantina revisitada por Mayorga, asistimos a un diálogo picaresco en un campo de refugiados. Los personajes perros se dan cuenta que, en su vida anterior, eran hombres, pero fueron convertidos en perros por el trato que recibieron. Al final, ante la amenaza del humano, deciden "luchar" e irse "a un lugar mejor. A un lugar donde ser hombres” (Mayorga, 2004, 57). Cae el telón, la esperanza queda "en suspensión", se dibuja el mapa de un lugar por venir, el camino hacia una salvación posible.

El tema de la salvación aparece en numerosas obras de Juan Mayorga. En la obra breve Concierto fatal de la viuda Kolakowski, la protagonista, amenazada por la urgencia de la guerra, repite "Si supiera cantar, me salvaría". Este "leitmotiv" es también el subtítulo del Crítico, y uno de los focos de la mirada elíptica mayorguiana. El canto que puede salvar a la hija de Gottfried al final de Himmelweg nos redime a todos en la búsqueda de "un lugar mejor".

Si lo haces bien, volveremos a ver a mamá. Ella va a venir en uno de esos trenes. Si hacemos lo que ellos nos piden. No vamos a perder la paciencia, ¿verdad, Rebeca? Lo haremos tantas veces como sea necesario para que 
mamá vuelva, ¿verdad que lo vamos a hacer tantas veces como haga falta? (...) Y luego, una canción. Quieren que cantes una canción, Bueno, no está mal, ¿no? Que nos manden cantar. ¿Te acuerdas de aquella que mamá te cantaba para dormir? Una canción para acabar. Canta la Niña la canción. La Niña se pone en pie, coge el muñeco y le canta (Mayorga, 2011, 171-172).

Una mirada esperanzadora hacia la Historia puede "salvar el pasado", como expone Juan Mayorga en su tesis doctoral:

El historiador benjaminiano dirige al pasado una mirada actual. Salvar el pasado consiste en hacer que el presente se reconozca mentado en él. Benjamin anota en el trabajo sobre los pasajes que "cada presente es determinado a través de aquellas imágenes que son sincrónicas con él; cada ahora es el ahora de una determinada reconocibilidad" (Mayorga, 2005, 60).

En la contemplación actual de la catástrofe, se elabora una cartografía de las ausencias, en la ruina y en la desesperanza nace la esperanza. Para finalizar, dejaremos de nuevo la palabra a Juan Mayorga, con una afirmación que nos resulta absolutamente actual: "el capitalismo lleva a un estado mundial de desesperación por el que precisamente se espera” (Mayorga, 2003, 238).

\section{REFERENCIAS BIBLIOGRÁFICAS}

Agamben, Giorgio. Enfance et histoire. Paris: Payot, 2002.

Benjamin, Walter. Euvres t.III. Paris: Gallimard, 2000.

Bensaïd, Daniel. Walter Benjamin, Sentinelle messianique. Paris: Les Prairies ordinaires, 2010.

Blanco Aguinaga, Carlos. "Cervantes y la picaresca”. In: Nueva Revista de Filología Hispánica, Ciudad de México, v. 11, n. 3-4, p. 314-342, ago. 1957. Disponível 
em: <https://nrfh.colmex.mx/index.php/nrfh/article/view/1334/1323>. Acesso em: 30 abr. 2021.

Brignone, Germán. "Huellas de la Poética de Aristóteles". In: Brizuela, Mabel (org.). Un espejo que se despliega. El teatro de Juan Mayorga. Córdoba: Universidad Nacional de Córdoba, 2011.

Deleuze, Gilles; Guattari, Félix. KAFKA. Pour une littérature mineure. Paris: Minuit, 1989.

Derrida, Jacques. L'écriture et la différence. Paris: Seuil, 1967.

Galeano, Eduardo. "Memorias y desmemorias". In: Le Monde Diplomatique, Paris, jul.-ago. 1997.

Mayorga, Juan. Revolución conservadora y conservación revolucionaria. Politica y memoria en Walter Benjamin. Barcelona: Anthropos, 2003.

Mayorga, Juan. "El teatro es un arte político". In: ADE Teatro, 95, 2003, 10.

Mayorga, Juan. Palabra de perro. El gordo y el flaco. Madrid: Teatro del Astillero, 2004.

Mayorga, Juan. Teatro para minutos. Ciudad Real: Ñaque, 2009.

Mayorga, Juan. "Elipses de Benjamin”. In: Constelaciones: Revista de Teoría Crítica, 2, 2010, 372-374.

Mayorga, Juan. Himmelweg. Ciudad Real: Ñaque, 2011.

Mayorga, Juan. Teatro 1989-2014. Segovia: La uÑa rota, 2014.

Mayorga, Juan. Elipses. Segovia: La uÑa rota, 2016.

Mayorga, Juan. La Colección, obra inédita, 2020.

Ortel, Philippe. Discours image dispositif. Paris: L'Harmattan, 2008. 
Perales, Liz. "Como los mapas, ninguna obra de teatro es neutral". In: El Cultural. Madrid, 26 abr. 2011. Disponível em: <https://elcultural.com/juan-mayorgacomo-los-mapas-ninguna-obra-de-teatro-es-neutral>. Acesso em: 20 dez. 2020.

Rancière, Jacques. Le destin des images. Paris: La Fabrique Edititions, 2003.

Spooner, Claire. De la scène au monde à travers le prisme du langage. Tesis inédita, defendida en cotutela entre la Universidad de Toulouse-Jean Jaurès y la Universidad Autónoma de Barcelona, 2013.

Ubersfeld, Anne. Lire le théâtre I. Paris: Belin, 1996.

Vilar, Ruth; Artesano, Salva. "Conversación con Juan Mayorga". In: Pausa, 32, Barcelona: 2010. Disponível em: <https://www.revistapausa.cat/conversacioncon-juan-mayorga/>. Acesso em: 04 mai. 2021. 
